\title{
ENDOZOOCHORY - THE SOURCE OF WEDDING OF AGRICULTURAL CROPS
}

\author{
Ciontu Valentin ${ }^{1 *}$, Daniel Jalobă${ }^{1}$, Mihaela Şerban ${ }^{2}$, Victor Petcu ${ }^{2}$, Marga Grădilă ${ }^{1}$ \\ ${ }^{1}$ Research - Development Institute for Plant Protection, Bucharest Romania \\ ${ }^{2}$ National Agricultural Research and Development Institute Fundulea, Călăraşi, Romania
}

\author{
*Correspondence address: \\ Research-Development Institute for Plant Protection \\ 8 Ion Ionescu de la Brad 013813, Bucarest, Romania \\ Phone: + 40212693231 \\ Fax: + 40212693239 \\ e-mail: ciontu.valentin96@yahoo.ro \\ http://www.doi.org/10.54574/RJPP.13.07
}

\begin{abstract}
One of the most important sources of weed infestation in agricultural crops is related to manure applied as biological fertilizer, when livestock growers don`t process it and don`t store it in order to be weeds free. In manure there are lot of weed seeds from animal fodder, livestock bedding and also from animal excrements. On the pasture, when grazing fresh food, animals eat also the inflorescences with weed seeds. Ones of these seeds could pass through the digestive tract of animals while keeping their ability to germinate. The aim of this study was to record the weed species that can cross over the digestive tract without losing their germination, to note which weed species are more adapted to do this, which animal species are able to perform the endozoochory process and under what environmental conditions. Trials were conducted under laboratory conditions. The content of excrements taken from four animals species (cattle, goats, sheep, horses), from four distinct South - East areas in period 2019-2020, were mixed with sterilized soil and put to germinate under controlled conditions of temperature and humidity. Following the assessments, weed seeds were found to be able to cross over the digestive tract of animals maintaining their germination. The highest frequency was in cattle and the lowest was in horses. There was at Pasărea where the largest number of weeds was found and animals grazed on untillaged land (hences, fallow lands). The dominant weed species were Setaria sp., Chenopodium sp., Amaranthus retroflexus and Polygonum aviculare.
\end{abstract}

Keywords: endozoochory, weed seeds, manure, germination.

\section{INTRODUCTION}

Weeds cause huge damage to agriculture, but also to other sectors of the economy. Damage caused by weeds to agricultural crops is reflected by diminution of the level of production, decreasing the quality of crops and by increasing production costs (Anghel et al., 1972; Șarpe et al., 1976; Șarpe \& Strejan, 1981; Șarpe, 1987; Budoi \& Penescu, 1996; Mortimer, 1996; Post \& Wijnants, 1996; Berca \& Tănase, 2000; Chirilă, 2001; Penescu \& Ciontu, 2001; Slonovschi et al., 2001; Berca, 2004, Grădilă et al., 2018; Jităreanu et al., 2020). The damage caused by weeds to agricultural crops is very diverse, large-scale and irrecoverable. Alongside the development of agriculture, weeds have continuously diversified and adapted to the conditions imposed by agricultural technology. Due to these permanent adaptations, weeds have acquired over time some biological features that ensure their maintenance, multiplication and spread on agricultural land (Penescu et al., 2017). One of these permanent adaptations of weeds refers to the dispersal of seeds. Seed dispersal is an important process in the life cycle of most plants, influencing community composition and ecosystem stability (Nathan \& Muller-Landav, 2000). While plants can have short-distance dispersal mechanisms (autochory), they must rely on external vectors, such as water currents (hydrochory), wind (anemochory), and particularly animals (zoochory) for long distance dispersal (Ridley, 1930). Specifically, animals can disperse seeds either internally, when 
viable seeds are defecated after (endozoochory) or externally, when seeds get attached to the animals fur or feathers (epizoochory) (Van der Pijl, 1982). The light seeds with wings or plumes can more easily be transported by wind, and fleshy nutritious tissues attract animals that will disperse their seeds after ingesting the fruits (Howe \& Smallwood, 1982). One of the main sources of weed infestation of agricultural land it is represented by manure because it can contain a very large amount of seeds. Thus, according to some authors, 20 tons of unfermented manure can contain up to 10 million weed seeds, of which about 350.000 are able to germinate immediately (Davidescu, 1956; Dostatny \& Maluszynska, 2008; Penescu \& Ciontu, 2001; Jităreanu et al., 2020). The germination capacity of weed seeds, passed through the digestive tract of animals, is preserved to a greater or lesser extent, depending on the species of animals. Thus, in pigs, $24 \%$ of the weed seeds passed through the digestive tract retained their germination capacity, in cattle $23 \%$, in horses $12.9 \%$ and in sheep $10.7 \%$ (Ionescu-Şiseşti, 1955; Penescu \& Ciontu, 2001). Even weed seeds passed through the digestive tract of birds retain their germination, but to a lesser extent. Up to 600 weed seeds have been found in the goose and intestines of poultry, from 10 different species (*2010). Weed seeds, ingested by animals, which are fed on pasture or various more or less cultivated land, they can pass through the digestive tract of animals and do not completely lose their germination, thus realizing the endozoochory process. In this sense, the animals leave their manure at the place where they feed, on pastures, agricultural lands or other lands, representing an important source of weeding. In this paper we aimed to elucidate the contribution of endozoochory in the spread of weed seeds on land grazed or crossed by animals.

\section{MATERIALS AND METHODS}

The research and determinations have been carried at Research-Development Institute for Plant Protection Bucharest, in Laboratory for Testing and Evaluating the Effectiveness of Plant Protection Products in the period of 2019-2020.

As materials there were used dejection samples, of solid manure harvested from herbivorous animals (cattle, horses, goats and sheep), from 4 different locations in the southeast area of Romania, on the lands belonging to the localities: Dâlga (Călărași county) and Pasărea, Moara Domnească and Voluntari (Ilfov county).

The samples were collected in October 2019, after the crops were harvested, but before performing the basic soil works. The lands had enough weeds with inflorescences and seeds that had reached full maturity and the animals were allowed to feed freely throughout the day. Freshly deposited dung was immediately collected after defecation occurred, leaving behind the lowermost part of the dung to avoid contamination of seed with the soil surface. Collected dung of different animals was put together to obtain $300 \mathrm{~g}$ samples of each herbivore species. Immediately after dung collection, samples were brought in laboratory, spread out in trays and put to air dry until February 2020 when they were used in the experiment. Simultaneously with the collection of manure from each location, soil samples were taken and used as a substrate for seed germination. The soil samples were thermally sterilized in an oven at $70^{\circ} \mathrm{C}$ for 12 hours in order to destroy the germination of weed seeds. The experience included 16 samples (4 animal species x 4 locations) and a control check without manure served as controls to test for contamination of outside seeds, each sample being tested in 3 repetitions. In this study we used a method which is very comparable to recommended seed bank estimation through germination (Thompson et al., 1997). Vegetation pots measuring $60 \times 17 \times 10 \mathrm{~cm}$ were filled with $200 \mathrm{~g}$ of solid manure and $4 \mathrm{~kg}$ of sterile soil. The sterile soil was placed in two layers, the first layer of $8 \mathrm{~cm}$ at the base, followed by the 
layer of solid manure from animals and over it another layer of $1 \mathrm{~cm}$ of sterile soil. The manure samples were distributed in a thin layer to ensure that all seeds receiving enough light to germinate within a short time period (Ter Heerdt et al., 1996). The vegetation pots were kept under laboratory conditions at a temperature of $20^{\circ} \mathrm{C}$ and properly moistened with 100 $\mathrm{ml}$ of distilled water every 2 days starting with 27.02.2020 for two months (and emerging seedlings were recorded). After germination of weed seeds, they were counted and determined using weed identification guide atlas (Chirilă et al., 2000; Ciocârlan, 2009), classified by families and groups respectively monocotyledonous or dicotyledonous, annual and perennial. After identification, the weeds were immediately uprooted to avoid competition between seedlings and to prevent flowering.

\section{RESULTS AND DISCUSSIONS}

A large fraction of plants produce fruits that attract animals $(64 \%$ gymnosperm and $27 \%$ of angiosperm). By consuming them, animals can spread the seeds to more or less distant sites from the parent plant, thus contributing to plant regeneration and colonization of new sites (Traveset \& Willson, 1997; Ridley, 1930; Herrera \& Pellmyr, 2002).

The dung of large herbivores can contain germinable seeds of many plant species (Welch, 1985; Malo \& Suarez, 1995; Fleming \& Estrada, 1993, Pakeman et al., 2002) and the retention of seeds inside the digestive tract is long enough, so that seeds can be deposited several kilometers away from the parent plant (Pakeman, 2001; Vellend et al., 2003). Weed seeds do not completely lose their germination when they pass through the digestive tract of animals. In our study, the results obtained confirm that the dung of herbivores is an important vector for the dispersal of plants both in terms of the quantity of seeds and the number of species involved.

Thus, in the sample with solid cattle manure, most weeds emerged from the seeds that passed through the digestive tract of animals ranging from 102 to 173 , depending on the location (Table 1). The average in the 4 locations was 132.2 weeds per $200 \mathrm{~g}$ of manure. The weed species emerged were: Setaria sp. [(P) Beauv], Echinochloua crus-galli [(L) Beauv]and Digitaria sanguinalis [(L) Scop] belonging to the group of annual monocots and species Sorghum halepense [(L) Pers] within the perennial monocots group. There were present the dicotyledonous ones: Amaranthus retroflexus (L), Chenopodium sp. (L), Polygonum aviculare (L), Galium aparine (L), Stellaria media (Vill), Sinapis arvensis (L) and Raphanus raphanistrum (L). The following species had a higher share of over 10\%: Setaria sp., 26.65\%, Chenopodium sp., $18.90 \%$, A. retroflexus $17.96 \%$ and $P$. aviculare $13.61 \%$ (Table 1).

In horses, the average number of weeds was very small, 3.25 weeds to $200 \mathrm{~g}$ of manure, and in two locations, at Moara Domnească and Voluntari, no weeds emerged. This shows that the seeds that cross the horse's digestive tract lose their germination capacity to a very large degree. The weed species that emerged from the horse manure were Poa annua (L.), S. media, P. aviculare and A. retroflexus. The obtained results demonstrate that the germination capacity of the weed seeds, passed through the digestive tract of the animals, is preserved to a greater or lesser extent, depending on the species (Figure 1).

It is not known exactly the factors that determine the total amount of seeds dispersed by ingestion and defecation by large herbivores. There are hypotheses that the density of seeds in the manure of herbivores depends on the size of the seeds, their shape and hardness as well as on the fertility and the degree of supply of the soil with seeds. Fruit consumers, specifically, may show preferences for fruit traits such as size, shape, chemical composition and others, and have specific morphologies and physiologies of the digestive tract that affect the survival probability of the ingested seeds in different ways (Herrera \& Pellmyr, 2002). 
Some research suggests that several characteristics of the seeds, including taste and production, have co-evolved to achieve endozoochory.

Table 1. Number and species of weeds recorded in manure samples

\begin{tabular}{|c|c|c|c|c|c|c|c|c|c|}
\hline \multirow[t]{3}{*}{ Location } & \multirow{3}{*}{$\begin{array}{l}\text { Animal } \\
\text { species }\end{array}$} & \multirow{3}{*}{$\begin{array}{c}\text { No. of } \\
\text { weeds/ } \\
200 \mathrm{~g} \\
\text { manure }\end{array}$} & \multirow{3}{*}{$\begin{array}{l}\text { No. of } \\
\text { weeds/ } \\
\text { ton } \\
\text { manure }\end{array}$} & \multicolumn{6}{|c|}{ Weed species emerged in the order of dominance } \\
\hline & & & & \multicolumn{3}{|c|}{ Monocotyledonous } & \multicolumn{3}{|c|}{ Dicotyledonous } \\
\hline & & & & Weeds & No. & $(\%)$ & Weeds & No. & $(\%)$ \\
\hline \multicolumn{2}{|c|}{ Control sample } & - & - & - & - & - & - & - & - \\
\hline \multirow{20}{*}{$\begin{array}{l}\text { Dâlga, } \\
\text { Călăraşi }\end{array}$} & \multirow{7}{*}{ Cattle } & \multirow{7}{*}{121} & \multirow{7}{*}{605000} & Setaria sp. & 27 & 22.32 & Chenopodium sp. & 22 & 18.18 \\
\hline & & & & D. sanguinalis & 10 & 8.27 & A. retroflexus & 20 & 16.53 \\
\hline & & & & E. crus-galli & 8 & 6.61 & P. aviculare & 14 & 11.57 \\
\hline & & & & S. halepense & 5 & 4.13 & G. aparine & 7 & 5.79 \\
\hline & & & & & & & S. media & 4 & 3.30 \\
\hline & & & & & & & S. arvensis & 2 & 1.65 \\
\hline & & & & & & & R. raphanistrum & 2 & 1.65 \\
\hline & \multirow[t]{2}{*}{ Horses } & \multirow[t]{2}{*}{8} & \multirow[t]{2}{*}{40000} & P. аппиа & 5 & 62.50 & S. media & 2 & 25.00 \\
\hline & & & & & & & P. aviculare & 1 & 12.50 \\
\hline & \multirow{6}{*}{ Goats } & \multirow{6}{*}{58} & \multirow{6}{*}{290000} & Setaria sp. & 16 & 27.59 & P. aviculare & 14 & 24.14 \\
\hline & & & & E. crus-galli & 4 & 6.90 & Chenopodium sp. & 7 & 12.07 \\
\hline & & & & D. sanguinalis & 3 & 5.17 & A. retroflexus & 5 & 8.62 \\
\hline & & & & S. halepense & 3 & 5.17 & G. aparine & 4 & 6.90 \\
\hline & & & & & & & S. media & 1 & 1.72 \\
\hline & & & & & & & R. raphanistrum & 1 & 1.72 \\
\hline & & & & Setaria sp. & 7 & 20.59 & Chenopodium sp. & 7 & 20.59 \\
\hline & & & & D. sanguinalis & 3 & 8.82 & A. retroflexus & 6 & 17.65 \\
\hline & Sheep & 34 & 170000 & E. crus-galli & 3 & 8.82 & P. aviculare & 5 & 14.71 \\
\hline & & & & S. halepense & 1 & 2.94 & G. aparine & 1 & 2.94 \\
\hline & & & & & & & S. media & 1 & 2.94 \\
\hline \multirow{27}{*}{$\begin{array}{l}\text { Pasărea, } \\
\text { Ilfov }\end{array}$} & & & & Setaria $s p$ & 49 & 28.32 & Chenopodium sp. & 31 & 17.92 \\
\hline & & & & E. crus-galli & 10 & 5.79 & A. retroflexus & 29 & 16.76 \\
\hline & & & & D. sanguinalis & 8 & 4.62 & P. aviculare & 21 & 12.14 \\
\hline & Cattle & 173 & 865000 & S. halepense & 5 & 2.90 & G. aparine & 8 & 4.62 \\
\hline & & & & & & & S. media & 4 & 2.31 \\
\hline & & & & & & & S. arvensis & 4 & 2.31 \\
\hline & & & & & & & R. raphanistrum & 4 & 2.31 \\
\hline & Horses & 5 & 25000 & & & & A. retroflexus & 3 & 60.00 \\
\hline & & & & & & & S. media & 2 & 40.00 \\
\hline & & & & Setaria sp. & 12 & 25.00 & Chenopodium sp. & 8 & 16.67 \\
\hline & & & & E. crus-galli & 3 & 6.25 & A. retroflexus & 8 & 16.67 \\
\hline & Goats & 48 & 240000 & D. sanguinalis & 3 & 6.25 & P. aviculare & 7 & 14.58 \\
\hline & & & & S. halepense & 2 & 4.17 & G. aparine & 3 & 6.25 \\
\hline & & & & & & & S. media & 1 & 2.08 \\
\hline & & & & & & & S. arvensis & 1 & 2.08 \\
\hline & & & & Setaria $s p$ & 15 & 25.00 & A. retroflexus & 11 & 18.33 \\
\hline & & & & E. crus-galli & 5 & 8.33 & Chenopodium sp. & 11 & 18.33 \\
\hline & Sheep & 60 & 300000 & D. sanguinalis & 4 & 6.67 & P. aviculare & 8 & 13.33 \\
\hline & & & & S. halepense & 2 & 3.34 & G. aparine & 3 & 5.00 \\
\hline & & & & & & & S. arvensis & 1 & 1.67 \\
\hline & & & & Setaria sp. & 26 & 25.50 & A. retroflexus & 21 & 20.58 \\
\hline & & & & E. crus-galli & 6 & 5.89 & P. aviculare & 20 & 19.61 \\
\hline & Cattle & 102 & 510000 & D. sanguinalis & 2 & 1.96 & Chenopodium sp. & 18 & 17.64 \\
\hline & Caltie & 102 & 310000 & & & & G. aparine & 4 & 3.92 \\
\hline & & & & & & & S. media & 2 & 1.96 \\
\hline & & & & & & & R. raphanistrum & 2 & 1.96 \\
\hline & & & & & & & S. arvensis & 1 & 0.98 \\
\hline
\end{tabular}


Romanian Journal for Plant Protection, Vol. XIII, 2020

ISSN 2248 - 129X; ISSN-L 2248 - 129X

\begin{tabular}{|c|c|c|c|c|c|c|c|c|c|}
\hline \multirow{12}{*}{$\begin{array}{l}\text { Moara } \\
\text { Domnească } \\
\text { Ifov }\end{array}$} & Horses & 0 & 0 & - & - & - & - & - & - \\
\hline & \multirow{6}{*}{ Goats } & \multirow{6}{*}{44} & \multirow{6}{*}{220000} & Setaria sp. & 9 & 20.45 & Chenopodium sp. & 9 & 20.45 \\
\hline & & & & E. crus-galli & 4 & 9.09 & A. retroflexus & 7 & 15.91 \\
\hline & & & & D. sanguinalis & 3 & 6.82 & P. aviculare & 5 & 11.36 \\
\hline & & & & & & & G. aparine & 3 & 6.82 \\
\hline & & & & & & & S. media & 2 & 4.55 \\
\hline & & & & & & & S. arvensis & 2 & 4.55 \\
\hline & & & & Setaria sp. & 6 & 22.22 & Chenopodium sp. & 5 & 18.52 \\
\hline & \multirow{4}{*}{ Sheep } & \multirow{4}{*}{27} & \multirow{4}{*}{135000} & E. crus-galli & 2 & 7.41 & A. retroflexus & 5 & 18.52 \\
\hline & & & & D. sanguinalis & 2 & 7.41 & P. aviculare & 3 & 11.11 \\
\hline & & & & S. halepense & 2 & 7.41 & S. arvensis & 1 & 3.70 \\
\hline & & & & & & & G. aparine & 1 & 3.70 \\
\hline \multirow{18}{*}{$\begin{array}{l}\text { Voluntari, } \\
\text { Ifov }\end{array}$} & \multirow[t]{6}{*}{ Cattle } & \multirow[t]{6}{*}{133} & \multirow[t]{6}{*}{665000} & Setaria sp. & 39 & 29.33 & Chenopodium sp. & 29 & 21.80 \\
\hline & & & & E. crus-galli & 9 & 6.77 & A. retroflexus & 25 & 18.80 \\
\hline & & & & S. halepense & 4 & 3.00 & P. aviculare & 17 & 12.79 \\
\hline & & & & & & & G. aparine & 6 & 4.51 \\
\hline & & & & & & & S. media & 2 & 1.50 \\
\hline & & & & & & & S. arvensis & 2 & 1.50 \\
\hline & Horses & 0 & 0 & - & - & - & - & - & - \\
\hline & \multirow[t]{5}{*}{ Goats } & \multirow[t]{5}{*}{35} & \multirow[t]{5}{*}{175000} & Setaria sp. & 8 & 22.86 & Chenopodium sp. & 6 & 17.14 \\
\hline & & & & D. sanguinalis & 3 & 8.57 & A. retroflexus & 6 & 17.14 \\
\hline & & & & E. crus-galli & 2 & 5.71 & P. aviculare & 5 & 14.30 \\
\hline & & & & S. halepense & 2 & 5.71 & G. aparine & 2 & 5.71 \\
\hline & & & & & & & S. media & 1 & 2.86 \\
\hline & Sheep & 53 & 265000 & Setaria $s p$ & 11 & 20.75 & Chenopodium sp. & 9 & 16.99 \\
\hline & & & & E. crus-galli & 5 & 9.43 & P. aviculare & 8 & 15.09 \\
\hline & & & & D. sanguinalis & 5 & 9.43 & A. retroflexus & 5 & 9.43 \\
\hline & & & & S. halepense & 3 & 5.69 & G. aparine & 5 & 9.43 \\
\hline & & & & & & & S. arvensis & 1 & 1.88 \\
\hline & & & & & & & S. media & 1 & 1.88 \\
\hline \multirow{23}{*}{ Mean } & \multirow{7}{*}{ Cattle } & \multirow{7}{*}{132.25} & \multirow{7}{*}{661000} & Setaria $s p$. & 35.25 & 26.65 & Chenopodium sp. & 25 & 18.90 \\
\hline & & & & E. crus-galli & 8.25 & 6.24 & A. retroflexus & 23.75 & 17.96 \\
\hline & & & & D. sanguinalis & 5 & 3.78 & P. aviculare & 18 & 13.61 \\
\hline & & & & S. halepense & 3.5 & 2.65 & G. aparine & 6.25 & 4.73 \\
\hline & & & & & & & S. media & 3 & 2.27 \\
\hline & & & & & & & S. arvensis & 2.25 & 1.70 \\
\hline & & & & & & & R. raphanistrum & 2 & 1.51 \\
\hline & & & & P. аппиа & 1.25 & 38.46 & S. media & 1 & 30.77 \\
\hline & Horses & 3.25 & 16250 & & & & A. retroflexus & 0.75 & 23.08 \\
\hline & & & & & & & P. aviculare & 0.25 & 7.69 \\
\hline & & & & Setaria sp. & 11.25 & 24.32 & P. aviculare & 7.75 & 16.76 \\
\hline & & & & E. crus-galli & 3.25 & 7.03 & Chenopodium sp. & 7.5 & 16.22 \\
\hline & & & & D. sanguinalis & 3 & 6.49 & A. retroflexus & 6.5 & 14.05 \\
\hline & & 4625 & & S. halepense & 1.75 & 3.78 & G. aparine & 3 & 6.49 \\
\hline & Goats & 46.25 & 231250 & & & & S. media & 1.25 & 2.70 \\
\hline & & & & & & & S. arvensis & 0.75 & 1.62 \\
\hline & & & & & & & R. raphanistrium & 0.25 & 0.54 \\
\hline & & & & Setaria $s p$ & 9.75 & 22.41 & Chenopodium sp. & 8 & 18.40 \\
\hline & & & & E. crus-galli & 3.75 & 8.62 & A. retroflexus & 6.75 & 15.51 \\
\hline & Sheep & 43.50 & 217500 & D. sanguinalis & 3.50 & 8.05 & P. aviculare & 6 & 13.80 \\
\hline & & & & S. halepense & 2 & 4.60 & G. aparine & 2.5 & 5.75 \\
\hline & & & & & & & S. arvensis & 0.75 & 1.72 \\
\hline & & & & & & & S. media & 0.50 & 1.14 \\
\hline
\end{tabular}

Thus small, round and hard seeds survive better in the digestive tract of animals compared to large, elongated and soft seeds (Russi et al., 1992; Gardner et al., 1993). Horses 
and cattle are both capable, to disperse large numbers of germinating seeds, but depending on the vegetation found in the location where the animals grazed and certain features specific to each species and also differences between the studied animals (Mouissie et al., 2005). Subtle variation in grazing behaviour and diet selection could explain some of the observed differences in germinating seed content between cattle and horses manure. Cattle and horses prefer grazing of graminoid rich habitats (Duncan, 1983; Menard et al. 2002). Within habitats horses will select very short grass dominated patches (P. annua and S. media.) in the case of our study. Whereas cattle prefer higher vegetation patches (Menard et al., 2002). Species of $D$. sanguinalis, E. crus-gali and $S$. halepense produce much more seeds compared to $P$. annua and $S$. media which could explain the smaller number of germinable seeds that pass through the digestive tract of horses. Also the differences between herbivores in terms of seed dispersal cannot be explained by differential seed survival (Simao et al., 1987) but rather by more selective foraging behaviour and more restricted habitat use of sheep. The suitability of manure as a colonisation site also differs between herbivores.

In goats and sheep, the average number of weeds was similar of 46.2 and respectively 43.5 at $200 \mathrm{~g}$ of manure and the dominant and close weed species were: Setaria sp. Chenopodium sp., A. retroflexus and $P$. aviculare. In the control sample, no weeds emerged.

One of the main sources of weed infestation for agricultural land is unfermented manure. The specialty literature reports cases when unfermented manure caused a mass invasion of weeds, which completely overwhelmed the vegetable plants (Dostatny \& Maluszynska, 2008; Sances \& Ingham, 1997; Barberi, 2002). Pleasant and Schlater in 1994 observed that $1 \mathrm{~kg}$ of cattle manure contained up to 42 viable Chenopodium album seeds and Zimdahl in 1993 reported that, in the same weed species, about $20 \%$ of the seeds ingested by cattle were able to withstand passage in the rumen and subsequent manure preparation and storage. Proper fertilization of manure is of great importance because weed seeds lose their viability depending on fermentation temperatures (Crafts \& Robbins, 1973; Nishida et al., 1998, Ozores-Hampton et al., 1999). At a temperature of $30-50^{\circ} \mathrm{C}$ during a 2 month fermentation, in summer, most of the weed seeds die. At a temperature of 30 degrees only part of the seeds die, and at a temperature of 10 degrees, all weed seeds remain alive, namely retains its germination power. Inside the manure pile, at a depth of $50 \mathrm{~cm}$, germination disappears faster and to a greater extent, while on the surface of the pile in the drier layer, the germination power is kept longer. Application of composted manure can substantially reduce weed emergence, especially of small seeded species, because of physical and chemical (via the production of leachates) effects (Ligneau \& Watt, 1995). The longer the fermentation, the higher the number of weed seeds that lose their germination. The hay we give to the animals must come from clean hayfields, otherwise the animal manure, fallen in the cultivated field or reached in the manure, is a source of weed emergence. Also, the bedding of animals, when it reaches the manure, is a source of infestation, if the straw in the bedding comes from infected fields. The weeds whose seeds appear most frequently in manure are: Chenopodium sp. and A. retroflexus. When the manure platform is not maintained in accordance with the regulations in force and especially when the manure pile is built on the ground, the weeds that grow near the pile and even on the pile, bear fruit and add to the mass of the manure an additional amount of often very large seeds. The same thing happens near the piles of manure taken to the field and left at the edge of the field. Therefore, manure platforms and the area around manure platforms and piles must be kept perfectly clean (Davidescu, 1956; Jităreanu, 2020; Penescu \& Ciontu, 2001; Budoi \& Penescu, 1996; **2015). It is known that doses of solid manure from animals can be applied in excess of $20 \mathrm{t} / \mathrm{ha}$. In this study the number of weeds raised per ton of solid manure from the 4 animal species was also calculated. It varies from 16.250 at 
horses to 217.500 at sheep, 231.250 at goats and reaches up to 661.000 at cattle (Table 1), the source of weeding through endozoochory being huge.

In the literature there is data on the number of dispersed seeds of animals so: the cattle disperse approximately 2.600 .000 seeds per animal per year and sheep 40.000 seeds per animal per year (Welch, 1985; Couvreur et. al., 2004). Therefore, manure should only be administered in the field after its fermentation at high temperatures, on specially designed platforms, because in this way, a large part of viable weed seeds lose their germination capacity, thus helping to reduce the weeding of agricultural crops.

Of the total weed species identified as the most abundantly and frequently family were the Poaceae and Amaranthaceae, the following in the lowest percentage were of the family Polygonaceae, Caryophyllaceae, Rubiaceae and Brassicaceae. The Poaceae family had an average for each animal species between $38.46 \%$ and $43.68 \%$ and the Amaranthaceae family between $23.08 \%$ and $36.86 \%$ (Table 2).

Table 2. Percentage recorded according to family of weed species

\begin{tabular}{|c|c|c|c|}
\hline Animal species & $\begin{array}{l}\text { Mean no. of weeds } \\
/ 200 \mathrm{~g} \text { manure }\end{array}$ & $\begin{array}{l}\text { Family of weed species in order } \\
\text { of dominance }\end{array}$ & $\begin{array}{c}\text { Percentage } \\
(\%)\end{array}$ \\
\hline \multirow{6}{*}{ Cattle } & \multirow{6}{*}{132.25} & Poaceae & 39.32 \\
\hline & & Amaranthaceae & 36.86 \\
\hline & & Polygonaceae & 13.61 \\
\hline & & Rubiaceae & 4.73 \\
\hline & & Brassicaceae & 3.21 \\
\hline & & Caryophyllaceae & 2.27 \\
\hline \multirow{4}{*}{ Horses } & \multirow{4}{*}{3.25} & Poaceae & 38.46 \\
\hline & & Caryophyllaceae & 30.77 \\
\hline & & Amaranthaceae & 23.08 \\
\hline & & Polygonaceae & 7.69 \\
\hline \multirow{6}{*}{ Goats } & \multirow{6}{*}{46.25} & Poaceae & 41.62 \\
\hline & & Amaranthaceae & 30.27 \\
\hline & & Polygonaceae & 16.76 \\
\hline & & Rubiaceae & 6.49 \\
\hline & & Caryophyllaceae & 2.70 \\
\hline & & Brassicaceae & 2.16 \\
\hline \multirow{6}{*}{ Sheep } & \multirow{6}{*}{43.50} & Poaceae & 43.68 \\
\hline & & Amaranthaceae & 33.91 \\
\hline & & Polygonaceae & 13.80 \\
\hline & & Rubiaceae & 5.75 \\
\hline & & Brassicaceae & 1.72 \\
\hline & & Caryophyllaceae & 1.14 \\
\hline Control sample & - & - & - \\
\hline
\end{tabular}

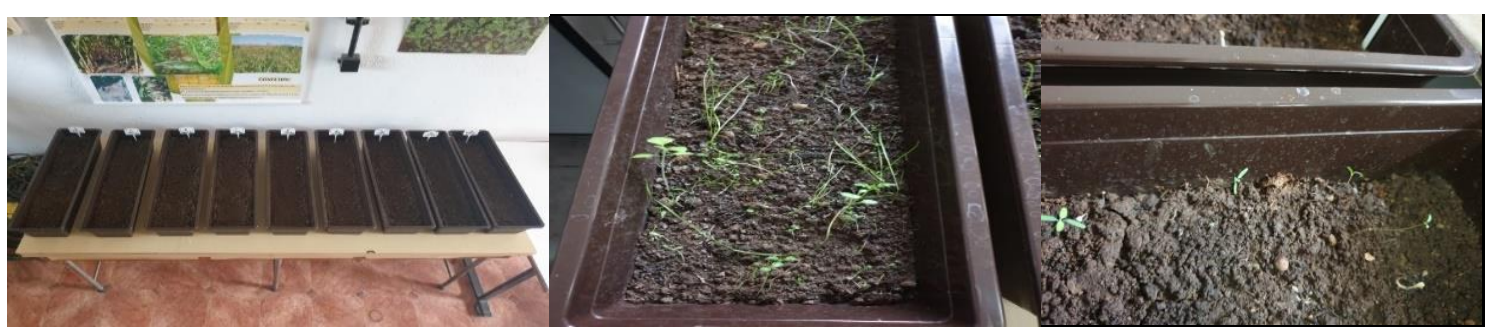

Figure 1. Aspects during the experiments 


\section{ACKNOWLEDGEMENTS:}

This work was supported by a grant of the Romanian Ministry of Research and Innovation, CCCDIUEFISCDI, project number PN-III-P1-1.2-PCCDI-2017-03-01/28PCCDI/2018, within PNCDI III.

\section{CONCLUSIONS}

The number of weed seeds that have passed through the digestive tract of animals, germinated and gave birth to a new generation of weeds, was the largest in solid cattle manure, followed by goats and sheep. The lowest number of weeds was recorded in horse manure.

According to the species of animals from which the manure was collected, a share of more than $20 \%$ had 5 species of weeds: Setaria sp., Chenopodium sp., A. retroflexus, P. annua and $S$. media.

The weed species that germinated from herbivores manure have usually small seeds and the ability to form a large number of seeds.

A large amount of seeds are dispersed by animals by endozoochory in agricultural ecosystems having a significant impact on crop weed infestation.

Manure must be applied in the field only after fermentation at high temperatures, on specially designed platforms, in compliance with all rules required by law.

The results of this study stress the potential of endozoochory by large herbivores as an important seed dispersal mechanism with a large number of seeds of a considerable number of plant species dispersed during the fruiting season.

\section{REFERENCES}

ANGHEL, GH., CHIRILĂ, C., CIOCÂRLAN, V., ULINICI, A. (1972). Buruienile din culturile agricole şi combaterea lor. Ed. Ceres, Bucureşti, 355p.

BARBERI, P. (2002). Weed management in organic agriculture: are we addressing the right issues. Weed Research, 42, 3, 177-193.

BERCA, M. (2004). Managementul integrat al buruienilor. Ed. Ceres, Bucureşti, 534p.

BERCA, M., TĂNASE, GH. (2000). Combaterea integrată a buruienilor. Al Xll-lea simpozion national de herbologie, Sinaia, 23-24.

BUDOI, GH., PENESCU, A. (1996). Agrotehnica. Ed. Ceres, Bucureşti, 425.

CHIRILĂ, C., CIOCÂRLAN, V., BERCA, M. (2000). Atlasul principalelor buruieni din România. Ed. Ceres, Bucureşti, 295.

CHIRILĂ, C. (2001). Biologia buruienilor, Ed. Ceres, București, 304p.

CIOCÂRLAN, V. (2009). Flora ilustrată a României: Pteridophyta şi Spermatophyta. Ed. Ceres, Bucureşti, 1141.

COUVREUR, M., CHRISTIAN, B., VERHRYEN, K., HERMY, M. (2004). Large herbivores as mobile links between isolated reserves trough adhesive seed dispersal. Applied Vegetation Science, 7 , 229-236.

CRAFTS, A.S., ROBIN, W.W. (1973). Weed Control. T.M.H. edition, Tata McGraw - Hill publishing company Ltd, New Delhi, 660.

DAVIDESCU, D., (1956). Agrochimia. Ed. Agro-Silvică de Stat, București, 896.

DOSTATNY, D.F., MALUSZYNSKA, E. (2008). Biology and life cycle of Chenopodium album L. on ecological cereal seed crops and in experimental conditions. Annuals UMCS, 55-63.

DUNCAN, P., (1983). Determinants of the use of habitat bv horses in a Mediterranean wetland. The Journal of Animal Ecology, 5293-109.

FLEMING, T.H., ESTRADA, A. (1993). General introduction. Vegetatio 107/108, xi-xii, 391. 
GARDNER, C.J., MCIVOR, J.G., JANSEN, A. (1993). Passage of legume and grass seeds through the digestive tract of cattle and their survival in faeces. Journal of Applied Ecology, 30, 63-74.

GRĂDILĂ, M., JALOBĂ, D., VASILE, N. (2018). Researches regarding weed control in winter wheat in the context of climate changes. Lucrări științifice, seria Agronomie Iași, 61, 2, 175-180.

HERRERA, C.M., PELLMYR, O. (2002). Plant-Animal Interactions: An Evolutionary Approach. Blackwell Publishing, Oxford, UK, 382p.

HOWE, H.F., SMALLWOOD, J. (1982). Ecology of seed dispersal. Annual Review of Ecology, Evolution and Systematics, 13, 201-228.

IONESCU-ŞISEŞTI, GH. (1955). Buruienile și combaterea lor. Ed. Agrosilvică de Stat Bucureşti, 234.

JitĂREANU, G., AILINCĂI, C., ALDA, S., ILEANA, B., CIONTU, C., MANEA, D., PENESCU, A., RURAC, M., RUSU, T., T,OPA, D., MORARU, P., POP, A.I., DOBRE, M., CALISTRU, A. (2020). Tratat de Agrotehnică. Ed. Ion Ionescu de la Brad, Iași, 1239p.

LIGNEAU, L., WATT, T. (1995). The effects of domestic compost upon the germination and emergence of barley and six arable weeds. Annals of Applied Biology, 126, 153-162.

MALO, J.E., SUAREZ, F. (1995). Herbivorous mammals as seed dispersers in a Mediterranean dehesa. Oecologia, 104, 246-255.

MENARD, C., DUNCAN, P., FLEURANCE, G., GEORGES, J.Y., LILA, M. (2002). Comparative foraging and nutrition of horses and cattle in European wetlands. Journal of Applied Ecology, 39,12013.

MORTIMER, M. A., (1996). Clasificarea şi ecologia buruienilor, Combaterea integrată a buruienilor, Al X-lea Simpozion Naţional de Herbologie, 249-264.

MOUISSIE, A.M., VOS, P., VERHAGEN, H.M., BAKKER, J.P. (2005). Endozoochory by freeranging, large herbivores - ecological correlates and perspectives for restoration. Basic Apply Ecology, 19, 478-486.

NATHAN, R., MULLER-LANDAV, H.C. (2000). Spatial patterns of seed dispersal, their determinants and consequences for recruitment. Trends in Ecology and Evolutio, 15, 278-285.

NISHIDA, T., SHIMIZU, N., ISHIDA, M., ONOUE, T., HARASHIMA, N. (1998). Effect of cattle digestion and of composting heat on weed seeds. Japanese Agricultural Research Quarterly, 32, 5560 .

OZORES-HAMPTON, M., STOFFELLA, P.J., BEWICK, T.A., CANTLIFFE, D.J., OBREZA, T.A. (1999). Effect of age of composted MSW and biosolids on weed seed germination. Compost Science and Utilization, 7, 51-57.

PAKEMAN, R.J. (2001). Plant migration rates and seed dispersal mechanisms. Journal of Biogeography, 28, 795-800.

PAKEMAN, R.J., Digneffe, G., SMALL, J.L. (2002). Ecological correlates of endozoochory by herbivores. Functional Ecology, 16, 296-304.

PENESCU, A., CIONTU, C. (2001). Agrotehnica. Ed. Ceres București, 436p.

PENESCU, A., IONESCU, N., GEORGESCU, M. I., SĂVULESCU, E., NICHITA, M., IONESCU, S. G. (2017). Compendiu de dinamica buruienilor. Ed. Ceres București, 283p.

POST, B.J., WIJNANTS, F.G. (1996). Combaterea integrată a buruienilor. Al X-lea Simpozion Naţional de Herbologie, Sinaia, 283-294.

PLEASANT, J., SCHLATER, K.J. (1994). Incidence of weed seed in cow (Bos spp.) manure and its importance as a weed source for cropland. Weed Technology, 8, 304-310.

RIDLEY, H.N. (1930). The dispersal of plants throughout the world. Reeve and Company, 744p.

RUSSI, L., COCKS, P.S., ROBERTS, E. H. (1992). The fate of legume seeds eaten by sheep from a Mediterranean grassland. Journal of Applied Ecology, 29, 772-778.

SANCES, F., INGHAM, E. (1997). Conventional and organic alternatives to methyl bromide on California strawberries. Compost Science and Utilization, 5, 23-37.

SIMAO, N., JONES, R. M., RATCLIFF, D. (1987). Recovery of pasture seed ingested by ruminants. Seed of six tropical pasture species fed to cattle sheep and goats. Australian Journal of Experimental Agriculture, 27, 239-246. 
SLONOVSCHI, V., NITA, M., NECHITA, A. (2001). Prezent şi viitor în combaterea buruienilor. Ed. Ion Ionescu de la Brad Iaşi, 293p.

ȘARPE, N., (1987). Combaterea integrată a buruienilor din culturile agricole. Ed. Ceres Bucuresti, 483p.

ŞARPE, N., STREJAN, GH. (1981). Combaterea chimică a buruienilor din culturile de câmp. Ed. Ceres București, 554p.

ŞARPE, N., CIORLĂUŞ, A., GHINEA, L., VLĂDUŢU, I., (1976). Erbicidele. Principiile și practica combaterii buruienilor. Ed. Ceres București, 361p.

TER HEERDT, G.N.J., VERWEIJ, G.L., BEKKER, R.M., BAKKER, J.P. (1996). An improved method for seed-bank analysis: Seedling emergence after removing the soil by sieving. British Ecological Society, 144-151.

THOMPSON, K., BAKKER, J.P., BEKKER, R.M. (1997). Soil Seed Banks of NW Europe: Methodology, Density and Longevity. Cambridge University Press, 369-373.

TRAVESET, A., WILLSON, M.F. (1997). Effect of birds and bears on seed germination of fleshy fruited plants in temperate rainforest of southeast Alaska. Oikos, 80, 89-95.

VAN DER PIJL, L. (1982). Principles of dispersal in higher plants. Springer-Verlag Berlin, 218p.

WELCH, D. (1985). Studies in the grazing of heather moorland in north-east Scotland IV seed dispersal and plant establishment in dung. Journal of Applied Ecology, 22, 461-472.

VELLEND, M., MYERS, J.A., GARDESCU, S., MARKS, P. L. (2003). Dispersal of Trillium seeds by deer: Implications for long-distance migration of forest herbs. Ecology, 84, 1067-1072.

ZIMDAHL, R.L. (1993). Weed biology: reproduction and dispersal, In: Fundamentals of Weed Science (ed. RL Zimdahl). Academic Press, San Diego, CA, USA, 59-89.

*(2010). Surse de îmburuienare în culturile agricole. Articol publicat pe data de 05 noiembrie 2010. https://agroromania.manager.ro/articole/stiri/surse-de-imburuienare-in-culturile-agricole-9430.html **(2015). Codul de bune practici agricole pentru protecția apelor împotriva poluării cu nitrați din surse agricole - realizat în cadrul proiectului 'Controlul Integrat al Poluării cu Nutrienți' prin contractul 24/CQ/2012. Editura eKarioka, 2015.

http://www.nitrati.ro/apps/Nitrati_data/website/Codul_de_bune_practici_agricole_pt_protectia_apelor _impotriva_poluarii_cu_nitrati_2015.pdf 